\title{
Investigation into the Impact Toughness of API 5L X80 Steel Weldments and its Relationship with Safe Welding Procedures
}

\author{
Thiago Rodrigues Carbos ${ }^{a}$ (1), Jorge Carlos Ferreira Jorge ${ }^{a^{*}}$ (1), Luís Felipe Guimarães de Souza ${ }^{a}$, \\ Ivani de Souza Bott ${ }^{b}$,Matheus Campolina Mendes ${ }^{a}$ (D)

\begin{abstract}
${ }^{a}$ Centro Federal de Educação Tecnológica Celso Suckow da Fonseca (CEFET/RJ), Departamento de Engenharia Mecânica, Av. Maracanã, 229, Maracanã, 20271-110, Rio de Janeiro, RJ, Brasil

${ }^{b}$ Pontificia Universidade Católica do Rio de Janeiro (PUC-RIO), Departamento de Engenharia Química e de Materiais, R. Marquês de S. Vicente, 225, Gávea, 22453-900, Rio de Janeiro, Brasil
\end{abstract}

Received: August 11, 2020; Revised: September 30, 2020; Accepted: November 02, 2020

\begin{abstract}
API 5L X80 steels are widely used in welded pipes in the petroleum industry. However, microstructural changes in the heat affected zone are a concern when welding such pipes due to the potential formation of regions with low toughness. Despite all the research concerning mechanical properties of welded joints, the acceptance criteria for the qualification of welding procedures are still limited. Welded joints do not always guarantee the safe operation of industrial equipment, because the current Standards adopted are not able to evaluate the properties at some critical regions of the welded joint. This work studied the characteristics of a girth welded joint and showed evidences of low toughness at $0.5 \mathrm{~mm}$ from the fusion line due to the micro-phases necklacing the prior austenite grain boundaries. As this feature is not considered by the current Standards for approval of welding procedures, this work proposes an alternative approach to improve the safety of welded structures.
\end{abstract}

Keywords: API 5L X80, welded joints, MA constituent, HAZ, impact toughness, microstructure.

\section{Introduction}

Population growth and industrial development in any country gives rise to a greater demand for petroleum products $^{1}$. The increase of oil and gas production and the consumption of their products worldwide have motivated new technology for alloy designs and processing of pipes. There are more stringent requirements for pipes with high strength-toughness combinations in order to reduce their weight and to decrease project $\operatorname{costs}^{2}$. Industrial pipes are very important for fluid transportation in the chemical, petrochemical, nuclear and petroleum industries. The American Petroleum Institute (API) provides specific standards for pipes to convey gas, water, and oil in the petrochemical industries, especially for oil and gas. The API $5 \mathrm{~L}^{3}$ specification describes the requirements for the chemical composition, tensile test characteristics and impact toughness behavior of these pipes. These requirements vary depending on the particular application and operating conditions. The basic requirements, however, are a combination of high mechanical strength and toughness at low temperatures and excellent weldability. As specified by API, materials are manufactured to attend two product specification levels known as PSL 1 and PSL 2. The PSL 2 level has stringent mandatory requirements for carbon equivalent and notch toughness in addition to the limits for yield strength and tensile strength. The term Carbon Equivalent (CE) is used to indicate the hardenability or

*e-mail: jorgecfjorge@gmail.com. crack susceptibility in the steel weld. CE also helps to estimate the combined effect of all the important alloying elements on the microstructure that occurs when welding steel. This is because this change in the microstructure of the steel is what defines its properties and behavior after the welding ${ }^{1}$. API has adopted two formulas $\left(\mathrm{CE}_{\mathrm{IIW}}\right.$ and $\left.\mathrm{CE}_{\mathrm{P}_{\mathrm{cm}}}\right)$ to specify the limit of carbon equivalent for API PSL2 grade pipe steel. $\mathrm{CE}_{\mathrm{IIW}}$ is used for carbon contents greater than $0.12 \%$ and $\mathrm{CE}_{\mathrm{Pcm}}$ for carbon contents less than $0.12 \%{ }^{3}$.

To assure the integrity of welded joints, the correct welding procedures must be selected to prevent the formation of defects and promote the acceptable properties ${ }^{4}$. However, even approved welding procedures are sometimes unable to avoid the occurrence of failures. Sharma et al. ${ }^{1}$ reviewed the possible causes of failures in pipelines and observed that the critical issues and challenges in welding of pipelines are corrosion, hydrogen embrittlement, residual stresses, weld repairing and a deteriorated heat affected zone which adversely affects the performance of a welded structure. The welding thermal cycle promotes changes in the microstructure and it can contribute to local brittleness in the Heat Affected Zone (HAZ) ${ }^{5-13}$.

The HAZ comprises several subzones: the coarse-grained HAZ (CGHAZ), the fine-grained HAZ (FGHAZ), the intercritical HAZ (ICHAZ), the subcritical HAZ (SCHAZ) and, in the case of multipass welds, the intercritically reheated CGHAZ (ICCGHAZ). Out of these zones, CGHAZ and ICCGHAZ usually have the lowest impact toughness of all 
the subzones in the weld ${ }^{8-11}$. The ICCGHAZ demonstrates even lower toughness than $\mathrm{CGHAZ}^{9-11}$.

API 5L X80 is a high strength steel which is usually applied in high-pressure pipelines to avoid the use of thicker pipes, allowing a more economic construction of long distance pipelines ${ }^{14}$. To use these pipes safely, it is necessary to evaluate the welding effects on the heataffected zone (HAZ) and weld metal properties carefully ${ }^{14}$. Regions presenting poor impact toughness in the HAZ of API X80 welded joints, known as local brittle zones (LBZ), have sometimes been observed ${ }^{7,10,11,14-21}$. Usually, the LBZ occurring in the ICCGHAZ are associated to the presence of MA constituents. Due to these observations there is extensive information addressing the effect of the morphology, size and distribution of MA constituents on the properties of the HAZ available in the literature ${ }^{7,10,11,14-31}$

Several studies have reported that the amount of MA constituents is the primary metallurgical factor affecting the impact properties ${ }^{24-30}$. Some works describe the deleterious effects of large volume fraction of the MA constituents on the impact toughness ${ }^{27,28}$. However, Kaplan and LambertPerlade $^{29}$ reported that the correlation between the toughness and total fraction of MA constituents might not be significant and this can be studied by focusing on massive and large MA fractions. Davis ${ }^{30}$ reported that the embrittlement of the HAZ is not only related to the amount of MA constituents but also to the particular microstructure.

Luo et al. ${ }^{18}$ stated that elongated MA constituents are more detrimental to toughness than massive ones. Conversely, Li et al. ${ }^{31}$ attributed the reduction of impact toughness to the increase in the volume fraction of the elongated MA constituents existing along the prior austenite grain boundaries.

Other researchers ${ }^{32,33}$ have shown that cracks tend to initiate at the interface between the coarse MA constituents and the matrix, and the size control of MA constituent is a key problem. Thus, it is recommended that the size of MA constituent should be minimized and the distribution more uniform $^{34,35}$

The size of the MA constituents can have a remarkable influence on the impact toughness. Zhong et al. ${ }^{36}$ suggested that a MA with a thickness of $\sim 20 \mathrm{~nm}$ could deflect brittle cracks and promote good impact toughness, while Li et al. ${ }^{37}$ stated that the critical size of MA constituents that could deteriorate the impact toughness is larger than $\sim 1.3-2 \mu \mathrm{m}$. This means that the MA size might not be the dominant factor that contributes to the variation of impact toughness ${ }^{9}$.

Another important issue is the decomposition of the MA constituents. If MA constituents are the main contributing factor affecting the impact toughness, their replacement would promote the elimination of the embrittlement and an improvement of the impact toughness would be expected. However, there are situations where this does not occur. Indeed, the presence of carbides is also deleterious to impact toughness ${ }^{38-40}$, and sometimes the coarser carbides are more detrimental to the Charpy-V toughness of the ICCGHAZ than the MA constituents ${ }^{39}$.

Interestingly, the same behavior is also observed in weld metals ${ }^{41,42}$, where MA constituents decompose into carbides during tempering, and the carbides distributed along the ferrite grain boundary worsen the low-temperature impact toughness even further ${ }^{41}$.

The above discussion shows that the mechanism by which the MA constituents affect the impact toughness of welded joints is still unclear, but it seems that the unique point where the literature converges is related to the detrimental effect of the MA constituents when they are surrounding the grain boundaries of prior austenite. Recently, Wang et al. ${ }^{9}$ stated that the variation in toughness of ICCGHAZ is not a concern, since obtaining high impact toughness is scarcely accessible even if the matrix microstructure is analogous to CGHAZ, due to the formation of a coarse necklace of MA constituents $(\sim 2 \mu \mathrm{m})$ around the prior austenite grain boundary.

Although Li et al. ${ }^{20}$ stated that the results obtained from simulations can be used to evaluate the impact toughness of the HAZ in actual welding joints, it is worth noting that a simulated area corresponds to one small point in the actual welded joint. Since most works are related to specific topics in small areas occupied by the LBZ, we can consider that the influence of the LBZ on the impact toughness is still an open discussion.

Furthermore there is as yet no fully comprehensive set of procedures for the safe operation of welded joints, because the effectiveness of the current Standards adopted for qualification of safe welding procedures must be reevaluated and, particularly, the position of the Charpy-V notch on the critical region is always an issue to be discussed ${ }^{43}$.

Based on this scenario, the present work investigated the microstructure and impact toughness of the HAZ of an API X80 welded joint at different positions from the fusion line, in order to present arguments contributing to safer welding procedures.

\section{Materials and Methods}

\subsection{Materials}

An API 5L X80M steel ${ }^{3}$ pipe produced by thermomechanical controlled rolling (TMCR) was used as the base material for a 22 inch NPS $(550 \mathrm{~mm})$ pipe. The samples used in the experiments were $410 \mathrm{~mm}$ long in the axial direction and $18 \mathrm{~mm}$ thick. Covered electrodes (AWS E 11018M), with $4 \mathrm{~mm}$ of diameter, were used as the welding consumables. Table 1 shows the chemical composition of the materials used by optical emission spectrometer.

\subsection{Welding}

Welding was performed in a flat position using the shielded metal arc welding process (SMAW). The preheat temperature was $100^{\circ} \mathrm{C}$ and the interpass temperatures were maintained at between 100 and $200^{\circ} \mathrm{C}$. The welding parameters are given in Table 2 . The joint geometry and the deposition sequence are shown Figure 1. A semi-V type groove $\left(45^{\circ}\right)$ was applied to locate the Charpy-V notch integrally at the HAZ.

After welding, post-welding heat treatment (PWHT) was performed at $600^{\circ} \mathrm{C}$ for 1 hour, followed by air-cooling. 


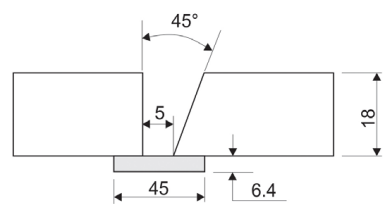

(a)

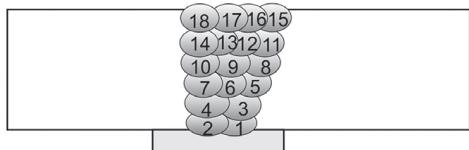

(b)

Figure 1. Joint geometry (a) and Deposition sequence (b).

Table 1. Chemical composition of the materials (wt, \%) used.

\begin{tabular}{ccccccccccccccccccc}
\hline Element & $\mathrm{C}$ & $\mathrm{Si}$ & $\mathrm{Mn}$ & $\mathrm{P}$ & $\mathrm{S}$ & $\mathrm{Cr}$ & $\mathrm{Mo}$ & $\mathrm{Ni}$ & $\mathrm{Cu}$ & $\mathrm{Ti}$ & $\mathrm{Nb}$ & $\mathrm{V}$ \\
\hline Base metal & 0.07 & 0.35 & 1.78 & 0.011 & 0.007 & 0.02 & 0.07 & 0.02 & 0.21 & 0.05 & 0.05 & 0.06 \\
\hline Weld metal & 0.08 & 0.42 & 1.56 & 0.018 & 0.007 & 0.27 & 0.29 & 1.54 & 0.08 & 0.01 & $<0.05$ & 0.01 \\
\hline
\end{tabular}

Table 2. Welding parameters

\begin{tabular}{cccc}
\hline Current (A) & Voltage (V) & $\begin{array}{c}\text { Average Welding } \\
\text { Energy }(\mathrm{kJ} / \mathrm{mm})\end{array}$ & $\begin{array}{c}\text { Number of } \\
\text { Passes }\end{array}$ \\
\hline $176-192$ & $25-31$ & 1.68 & 18 \\
\hline
\end{tabular}

\subsection{Mechanical tests}

Test specimens were extracted from $2 \mathrm{~mm}$ below the top surface for tension, Charpy- $\mathrm{V}$ and hardness tests, according to the requirements of the Standard for qualification of welding procedure ${ }^{44}$. For each condition, as welded and after PWHT, 2 specimens were used for the tension tests and 3 specimens were used for the Charpy-V impact test.

Tension tests were performed at room temperature on the test specimens removed transversally to the weld bead. The Charpy-V impact tests carried out at at $-29^{\circ} \mathrm{C}^{45}$ were also performed on standard test pieces $(10 \times 10 \times 55 \mathrm{~mm})$ removed transversally to the weld bead. The notch was positioned in the thickness section at positions corresponding to the center line of the weld metal, the fusion line (FL), 1.0, 2.0, 3.0 and $5.0 \mathrm{~mm}$ from the fusion line of the base metal, as shown in Figure 2.

Although not required by the Standards ${ }^{4-52}$, one additional set of Charpy-V notch specimens was obtained at $0.5 \mathrm{~mm}$ from the fusion line (Figure 2) to investigate the behavior of CGHAZ.

The hardness $\left(\mathrm{HV}_{10}\right)$ and microhardness $\left(\mathrm{HV}_{0.5}\right)$ tests were also performed on a test specimen removed transversally to the weld bead, using Vickers scale with a load of $10 \mathrm{kgf}$. and 500gf, respectively. The measurements were performed at the same positions where the notches for the Charpy-V impact tests were positioned. Additionally, tests were also conducted along the HAZ from the surface to the root at $0.25 \mathrm{~mm}$ from the fusion line.

\subsection{Metallographic examination}

Transverse sections were prepared and a detailed examination by optical (OM) and Scanning Electron Microscopy (SEM) was carried out to identify the microstructural constituents and micro-phases at the regions related to the Charpy- $\mathrm{V}$ notches shown in Figure 2.

The metallographic samples were carefully prepared using diamond paste as abrasive, followed by etching with Nital $2 \%$.

\section{Results and Discussion}

\subsection{Mechanical properties and microstructural characterization}

The macrograph in Figure 3 of the welded joint shows the effect of the multiple passes without signs of any defects. However, the fusion line presents some deviation from the designed geometry (Figure 1).

The tension tests show an ultimate tensile strength superior to the minimum required for API X80 $\mathrm{steel}^{3}$ and the facture occurring at the base metal (Figure 4). In addition, PWHT did not promote any significant changes $(<4 \%)$ to the tensile strength (Table 3 ).

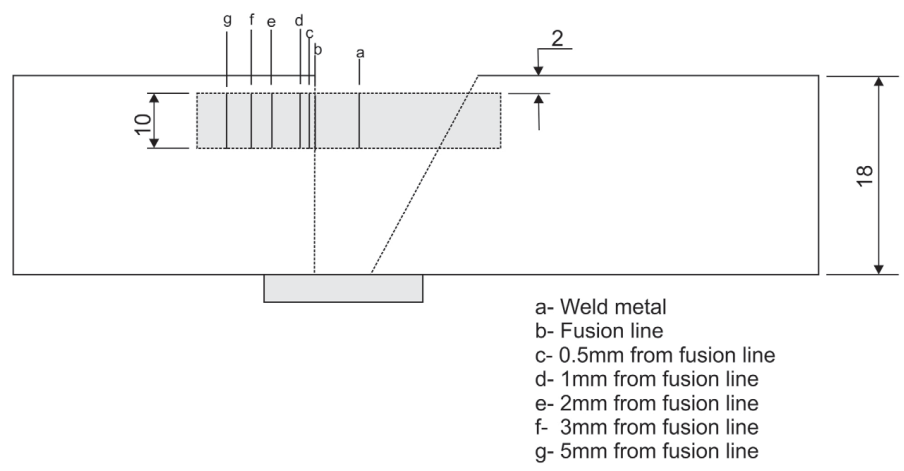

Figure 2. Standard full size Charpy V-notch specimen. 


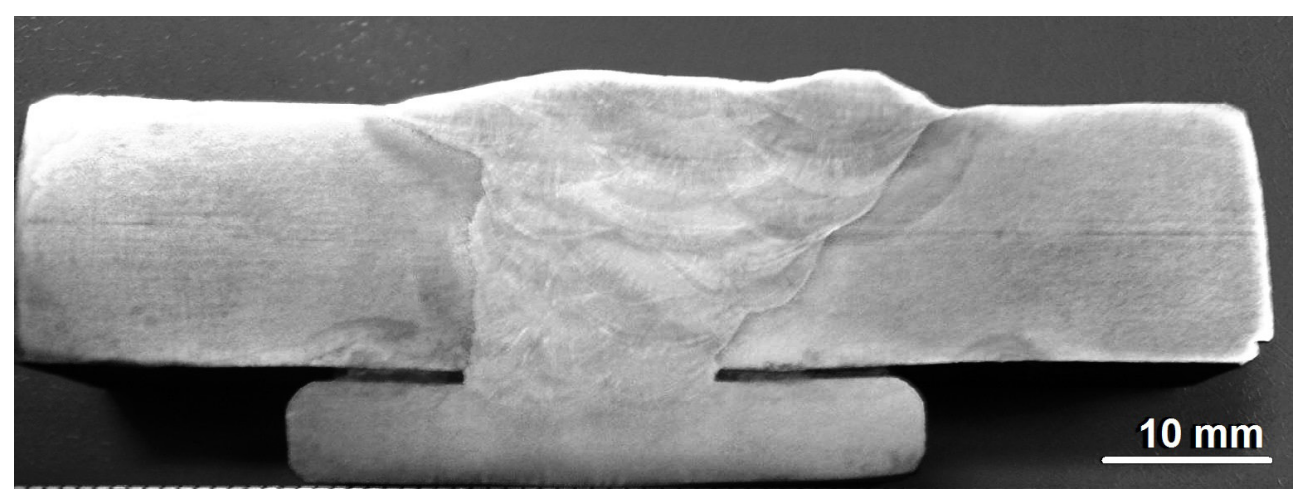

Figure 3. Macrograph of welded joint after etching with nital $2 \%$.

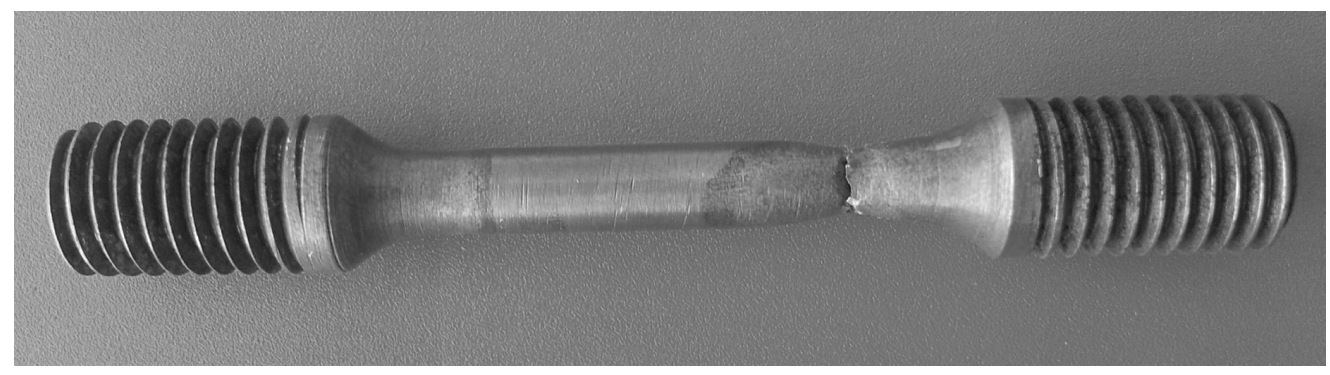

Figure 4. Detail of test specimen after tension test.

Table 3. Results of transverse tension tests.

\begin{tabular}{ccc}
\hline Condition & YS $(\mathrm{MPa})(*)$ & UTS $(\mathrm{MPa})(*)$ \\
\hline As welded & 652 & 684 \\
\hline PWHT & 596 & 662 \\
\hline Required $^{3}$ & 555 & 625 \\
\hline
\end{tabular}

Where: YS - Yield strength; UTS - Ultimate Tensile Strength.

Figures 5 and 6 show the microstructures representative of the positions relative to the Charpy- $\mathrm{V}$ notch and the corresponding microhardness.

The weld metal presented a refined microstructure composed of acicular ferrite (AF), primary ferrite $(\mathrm{PF})$ and ferrite with a second phase, as expected for $700 \mathrm{MPa}$ class steels ${ }^{53-64}$. This microstructure provided Charpy-V results much greater than the minimum required ${ }^{45}$, both in the as welded and heat treated conditions, as shown in Figure 7. These results indicate that the weld metal does not affect the mechanical behavior of the welded joint.

The effect of welding on the microstructure of the HAZ, is characterized by significant changes at different distances from the fusion line (Figure 5). The original microstructure consisting of ferrite and pearlite, also observed for $3.0 \mathrm{~mm}$ from the fusion line (3FL), is modified and lath and granular bainite are observed closer to the fusion line (1FL), which is consistent with other investigations ${ }^{18,21,65-67}$.

At $2.0 \mathrm{~mm}$ from the fusion line, lower microhardness values $(\sim 10 \%)$ compared to the base metal are observed, both in the as welded and heat treated conditions. This softening reported by the literature is usual in API X80 steel ${ }^{14,65,68-74}$, and is due to the predominance of polygonal ferrite ${ }^{65,72,73}$. However, some works ${ }^{14,68,74}$ state that the softening of HAZ may be more serious and a study on high-strength pipeline steel should not only pay attention to the embrittlement but also to the softening of the welding heat affected zone ${ }^{73}$, because the reduction in hardness can be around 10-20\% in comparison to the base metal ${ }^{70}$. Other works ${ }^{14,68-71}$ have shown that differences inferior to $10 \%$ are not problematic. This is in agreement with this work, where the reduction in hardness does not impair the mechanical properties of the welded joint, since the Charpy-V (Figure 7) and tension test (Table 3 ) results are greater than the minimum required and the fracture of the tension test specimen occurred at the base metal (Figure 4).

Thus, based on the results at the positions where the mechanical properties were measured and according to the Standards adopted ${ }^{3,44-52}$, the welding procedure could be inferred as suitable, despite the use of a more stringent methodology (semi-V groove). Indeed, the high Charpy-V results (Figure 7) and adequate UTS (Table 3) results along with the microhardness results are all in the range that is acceptable for approval ${ }^{51}$.

However, the most valuable finding is observed at $0.5 \mathrm{~mm}$ from the fusion line, where the impact toughness experiences a dramatic fall (Figure 7) and the fracture surface of the Charpy-V test specimen exhibits quasi-cleavage and intergranular features instead of dimples with different sizes distributed throughout the fracture surface, indicating micro void coalescence (Figure 8).

This unacceptable result is due to the occurrence of extensive precipitation of micro-phases along the prior austenite grain boundaries, both in the as welded (Figure 5) and heat treated conditions (Figure 6).

A detailed investigation conducted by SEM is shown in Figure 9 and here the presence of micro-phases decorating 


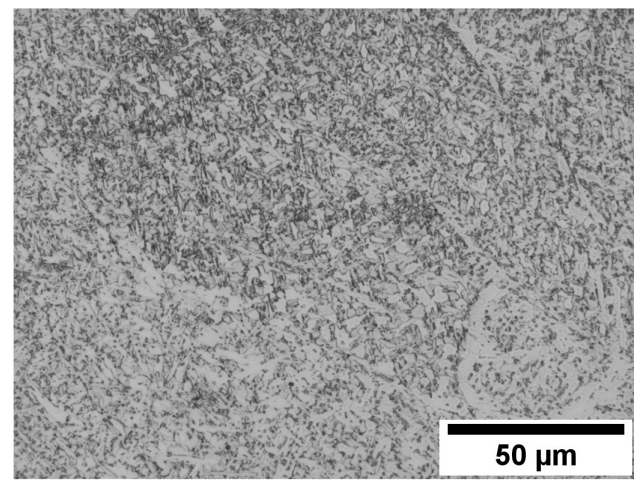

(a) $\mathrm{WM}\left(268 \mathrm{HV}_{0.5}\right)$

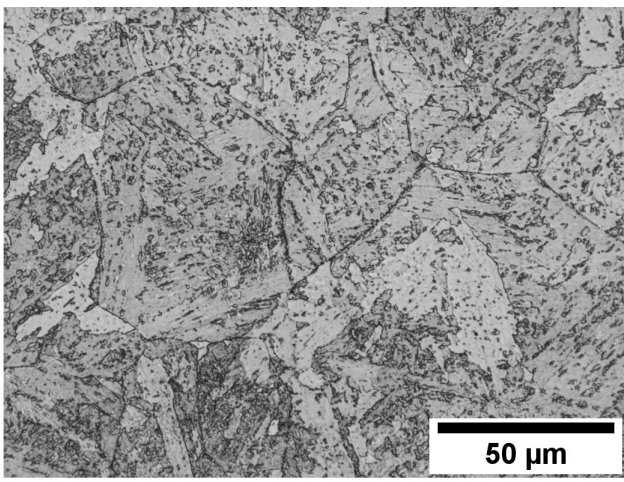

(c) $0.5 \mathrm{FL}\left(286 \mathrm{HV}_{0.5}\right)$

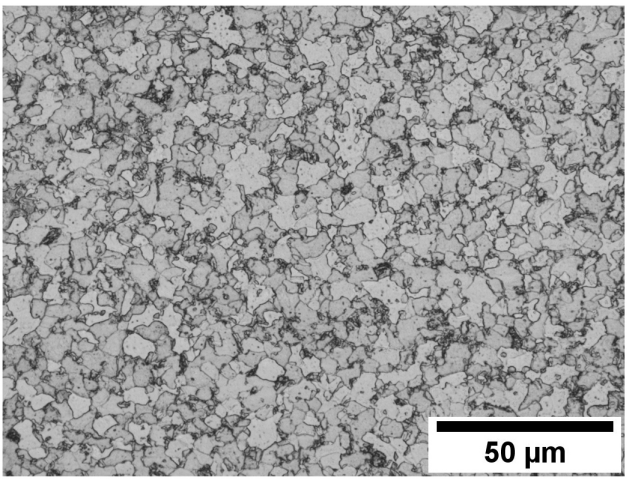

(e) $2 \mathrm{FL}\left(209 \mathrm{HV}_{0.5}\right)$

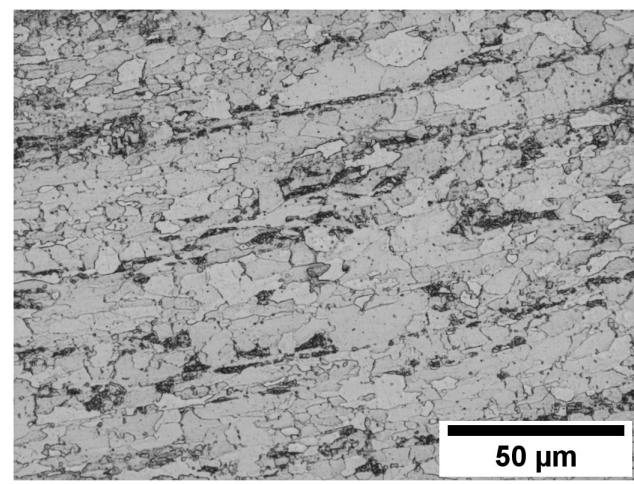

(g) $5 \mathrm{FL}\left(234 \mathrm{HV}_{0.5}\right)$

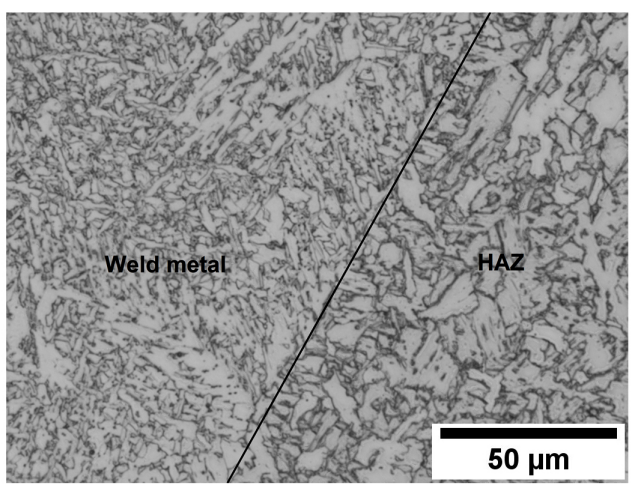

(b) FL (271 $\left.\mathrm{HV}_{0.5}\right)$

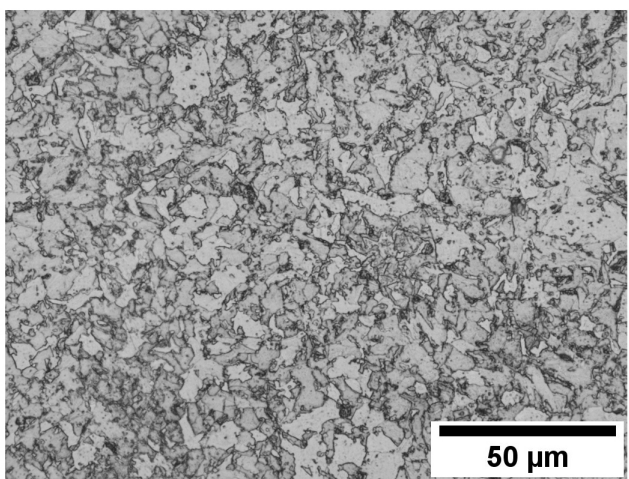

(d) 1FL (251 HV $\left.{ }_{0.5}\right)$

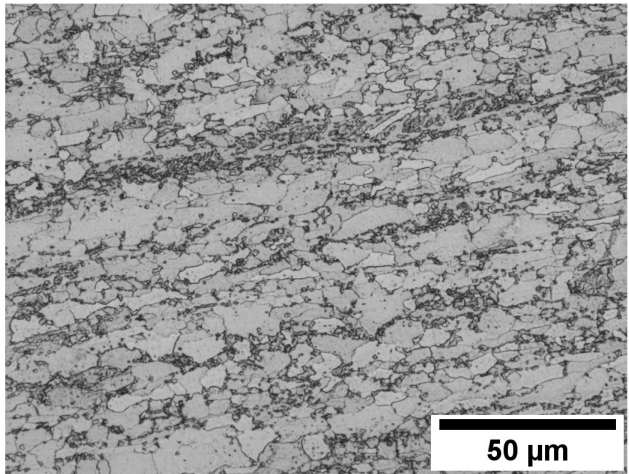

(f) $3 \mathrm{FL}\left(220 \mathrm{HV}_{0.5}\right)$

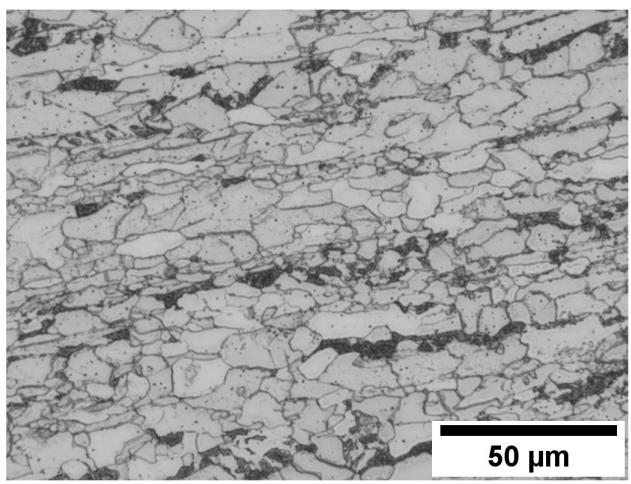

(h) 10FL (233 $\left.\mathrm{HV}_{0.5}\right)$

Figure 5. Microstructure at the positions relative to the Charpy-V notch in the as welded condition after etching with nital 2\% (OM). 


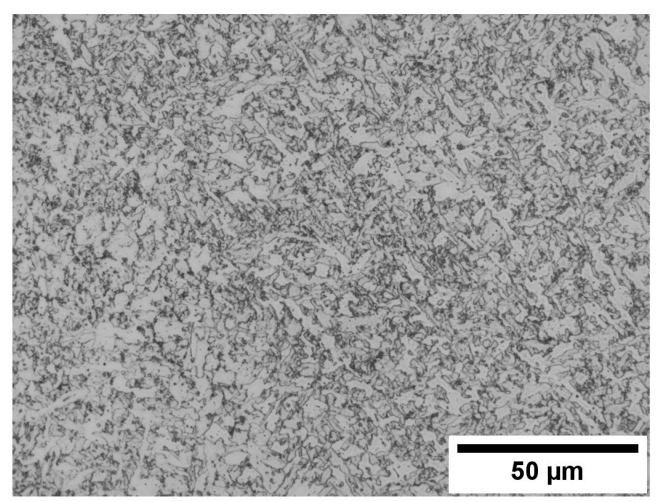

(a) $\mathrm{WM}\left(248 \mathrm{HV}_{0.5}\right)$

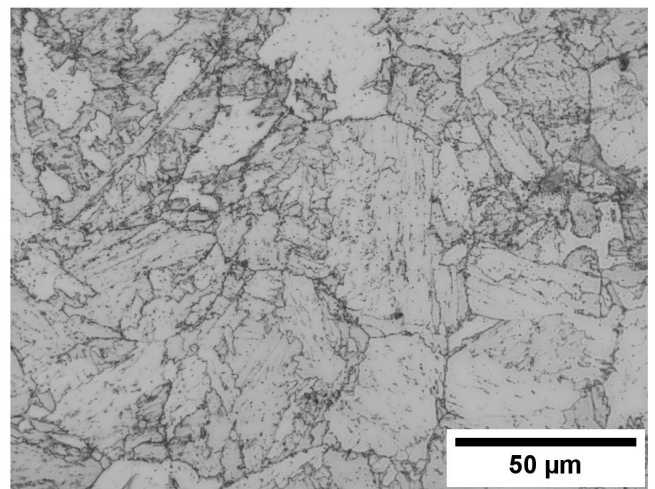

(c) $0.5 \mathrm{FL}\left(249 \mathrm{HV}_{0.5}\right)$

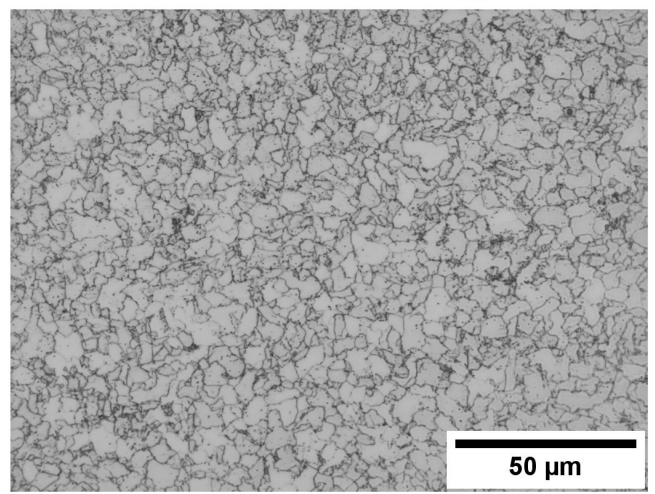

(e) $2 \mathrm{FL}\left(185 \mathrm{HV}_{0.5}\right)$

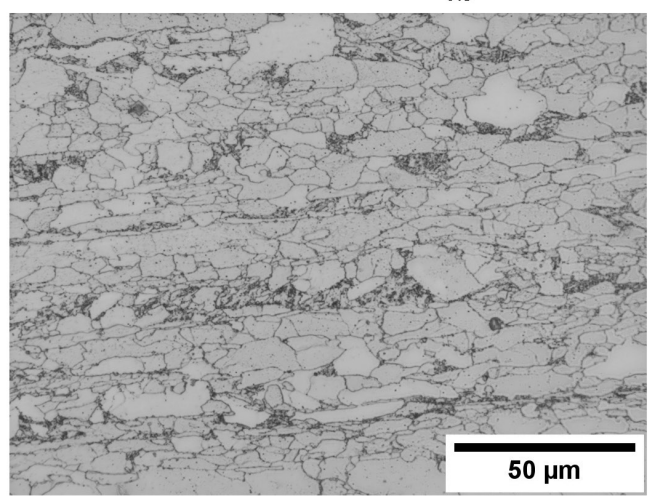

(g) $5 \mathrm{FL}\left(219 \mathrm{HV}_{0.5}\right)$

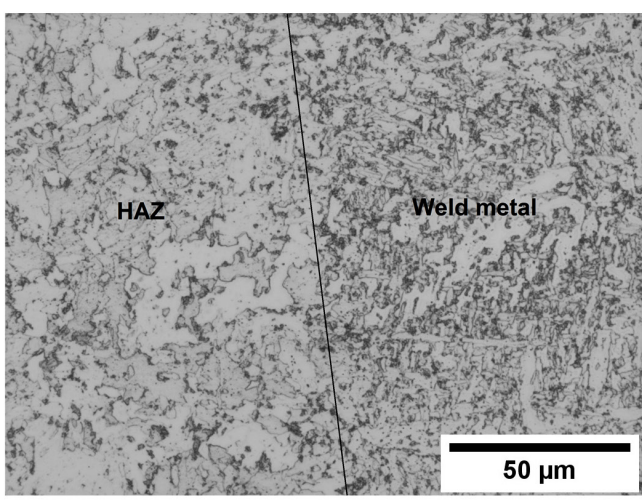

(b) FL (253 $\left.\mathrm{HV}_{0.5}\right)$

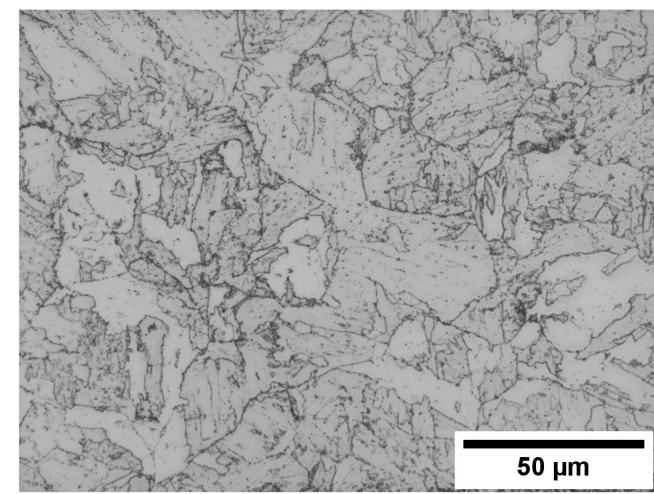

(d) $1 \mathrm{FL}\left(234 \mathrm{HV}_{0.5}\right)$

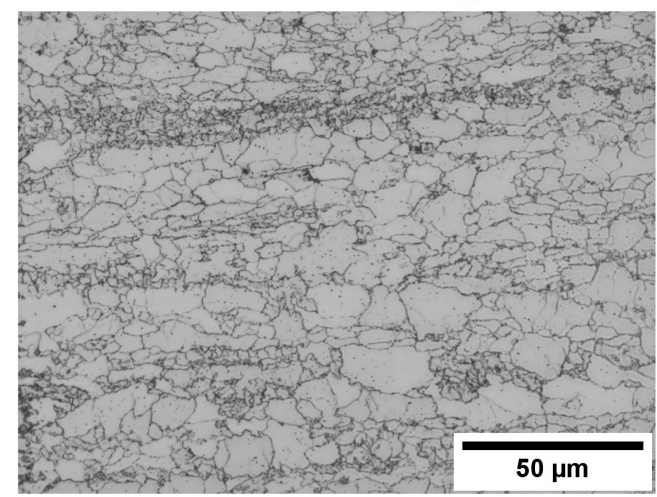

(f) $3 \mathrm{FL}\left(208 \mathrm{HV}_{0.5}\right)$

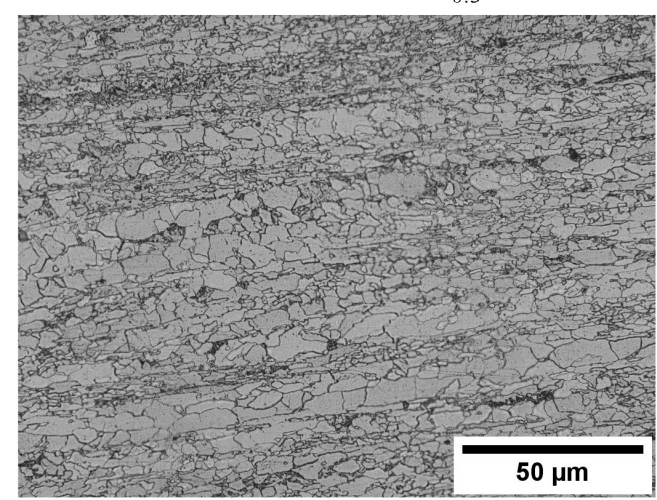

(h) $10 \mathrm{FL}\left(221 \mathrm{HV}_{0.5}\right)$

Figure 6. Microstructure at the positions relative to the Charpy-V notch in the heat treated condition after etching with nital $2 \%(\mathrm{OM})$. 


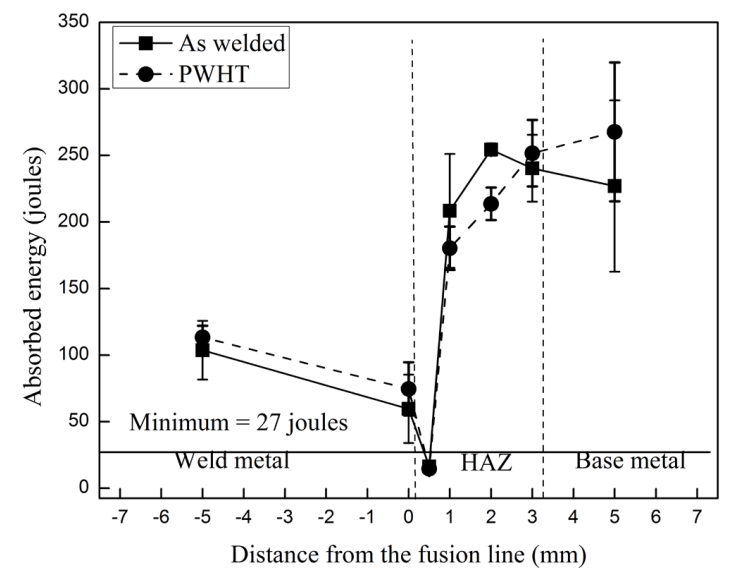

Figure 7. Results of Charpy-V impact tests performed at $-29^{\circ} \mathrm{C}$.

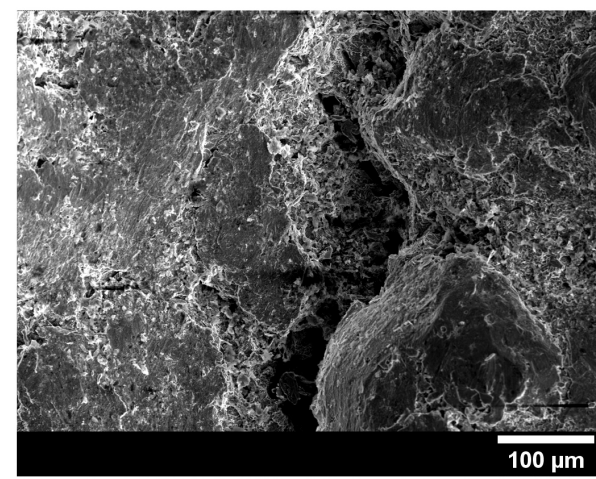

(a) the grain boundaries can be seen. However, contrarily to the hypotheses in the literature $9,10,12,13,19,20,29$, the continuous film of micro-phases is not composed solely of MA constituents as carbides are also present (Figure 9a). This can be seen more clearly in Figure 10, where the carbides and MA constituents, which have two different morphologies, are both present along the same grain boundary.

In addition, Figure $10 \mathrm{~b}$ reveals other areas along the thickness showing the partial decomposition of the MA constituents because of different thermal histories due to the multiple welding passes, which is presumably responsible for the deviation of cracks observed in the fracture path of the Charpy-V test specimen (Figure 11). Indeed, significant changes in the microhardness and microstructure along the thickness are observed, as shown in Figures 12 and 13.

The microhardness (Figure 12) does not show a continuous decrease with an increasing distance from the top surface

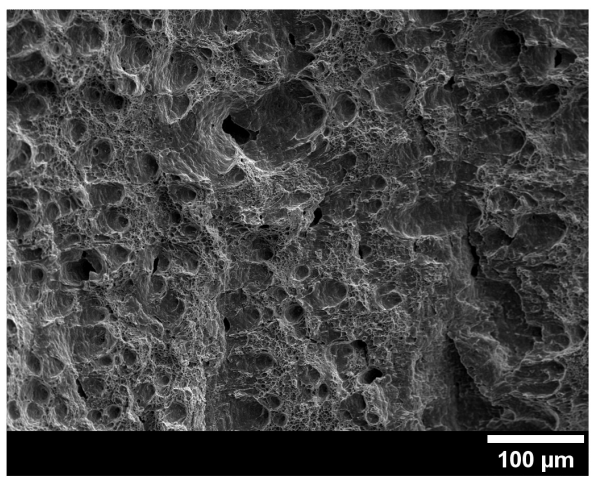

(b)

Figure 8. Characteristics of the fracture surface of the impact Charpy-V specimens (SEM). (a) $0.5 \mathrm{~mm}$ from the fusion line; (b) $1.0 \mathrm{~mm}$ from the fusion line.

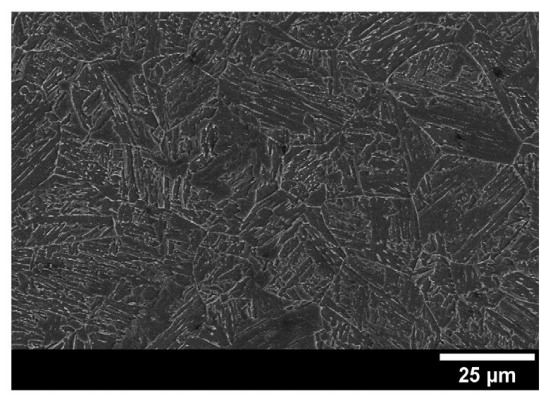

(a)

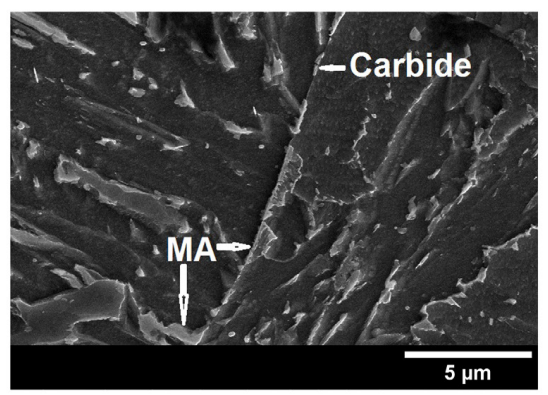

(c)

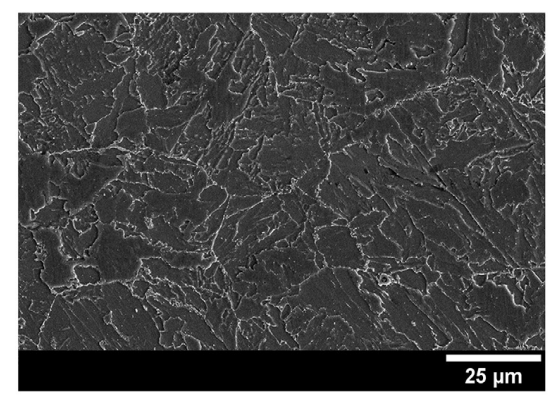

(b)

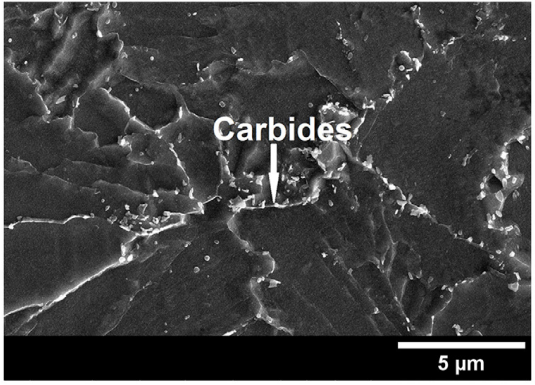

(d)

Figure 9. Micro-phases decorating the grain boundaries after etching with nital 2\% (SEM). (a), (c) as welded; (b), (d) PWHT. 
due to the effect of multiple reheating, as usually expected. This behavior can be attributed to the changes on the microstructure, because the presence of granular bainite and polygonal ferrite in different distances from the top surface (Figure 13) are responsible for different microhardness values (Figure 12). Also, it is worth noting that the increase in hardness at $8 \mathrm{~mm}$ from the top surface is due to another region presenting the grain boundaries decorated by microphases (Figure 13). As these microstructures show opposite effects on the impact toughness, polygonal ferrite contributes to high Charpy- $\mathrm{V}$ values while a region containing granular bainite with micro-phases decorating the grain boundaries is recognized as deleterious to the toughness, their proportion at the Charpy-V notch is the main concern. In this work, although the presence of a continuous film of micro-phases was observed for less than half of the Charpy-V notches (40\%), the impact toughness was very low (Figure 7), confirming the potent effect of micro-phases on this property. In addition, it contributes to show the complexity of the problem if evaluated by simulation experiments. For example, Li et al. ${ }^{21}$ suggest that there is a critical size for the MA constituent such that a controlled cleavage fracture is produced and suggested that the detrimental effect of MA with a size less than $3 \mu \mathrm{m}$ can be ignored. However, this value is superior to the one found in this work (Figure 10).

Another issue is related to the decomposition of MA constituents (Figure 9) and its effect on the impact toughness. In this work, the expected improvement of the impact toughness after PWHT was not observed (Figure 7) due to the presence of carbides distributed along the ferrite grain boundary (Figure 9b), as also observed in other works ${ }^{35-39}$. Thus, it can inferred that the distribution of micro-phases along the grain boundaries forming continuous films exerts the most powerful influence on the impact toughness, regardless of the composition, morphology and size of the micro-phases.

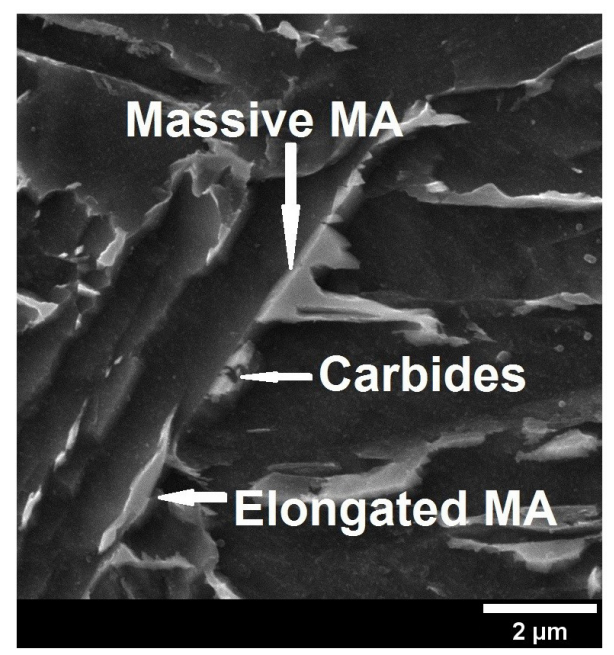

(a)

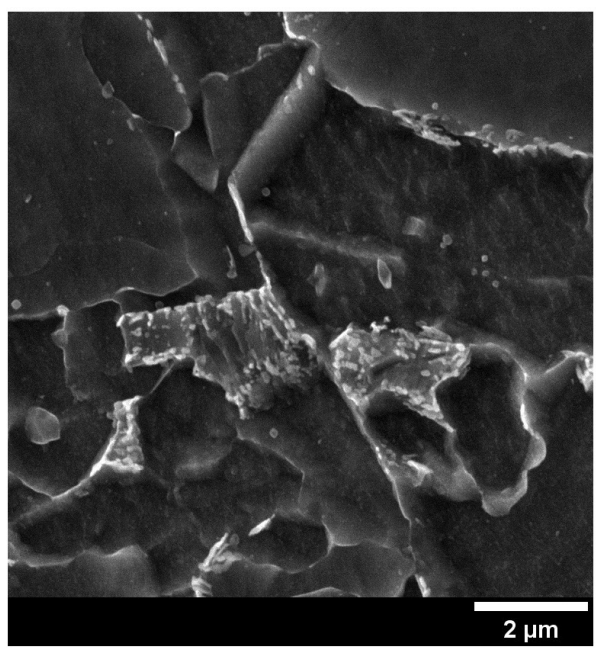

(b)

Figure 10. Characteristics of the micro-phases in different positions along the thickness after etching with nital 2\%. (a) Continuous film; (b) Degenerated MA.

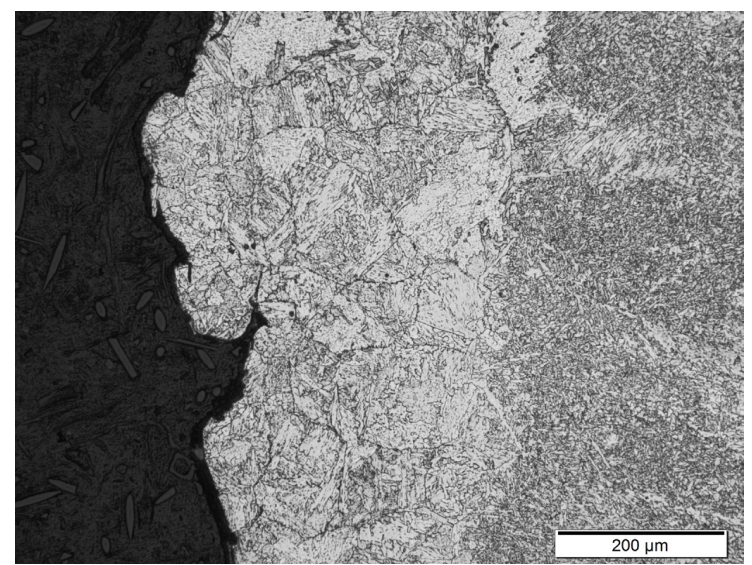

Figure 11. Aspect of the fracture path along the Charpy-V notch after etching with nital $2 \%(\mathrm{OM})$.

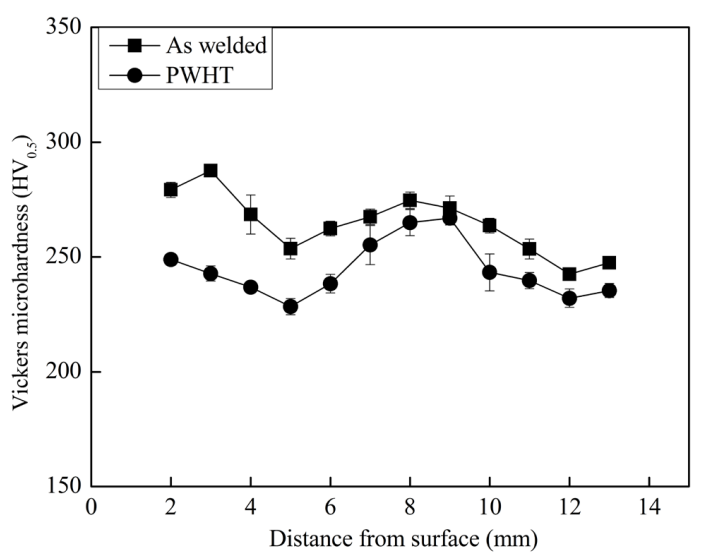

Figure 12. Microhardness along the HAZ at $0.25 \mathrm{~mm}$ from the fusion line. 


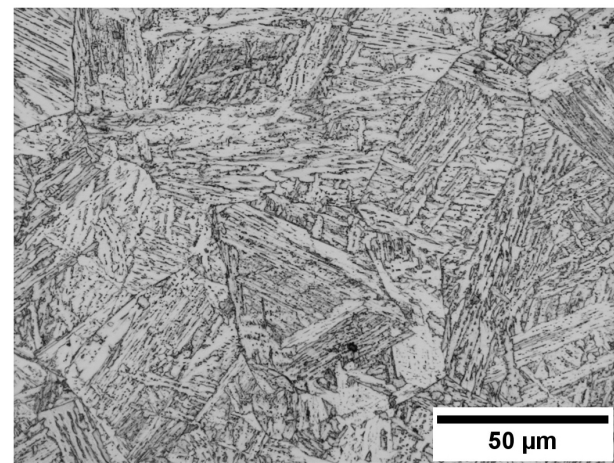

(a) $2 \mathrm{~mm}, \mathrm{LB}+\mathrm{GB}+$ micro-phases along the grain boundary

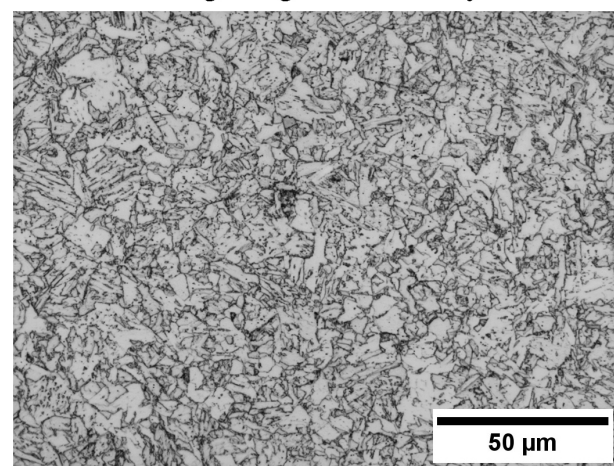

(c) $4 \mathrm{~mm}, \mathrm{~GB}+\mathrm{PF}$

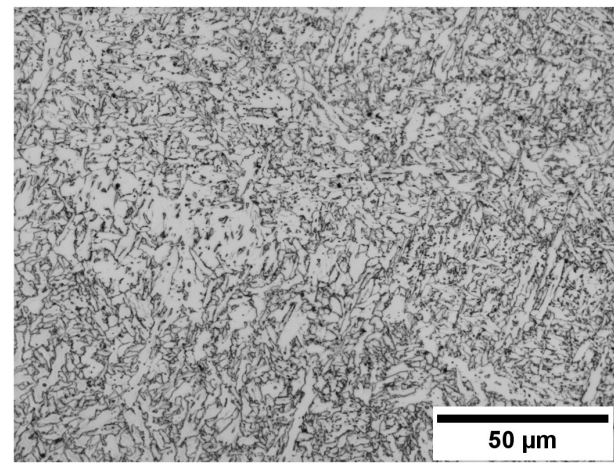

(e) $6 \mathrm{~mm}, \mathrm{~GB}+\mathrm{PF}$

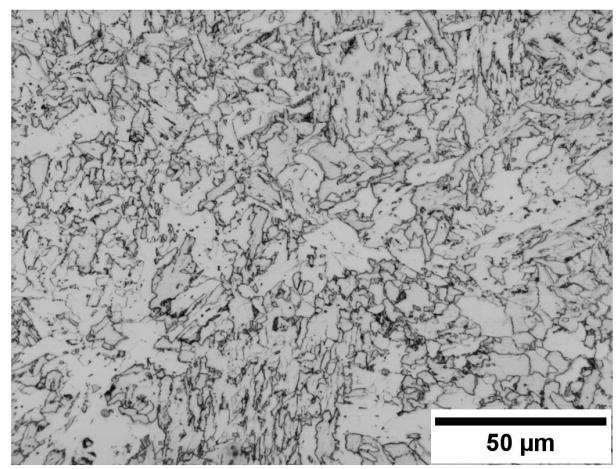

(g) $10 \mathrm{~mm}, \mathrm{PF}+\mathrm{GB}$

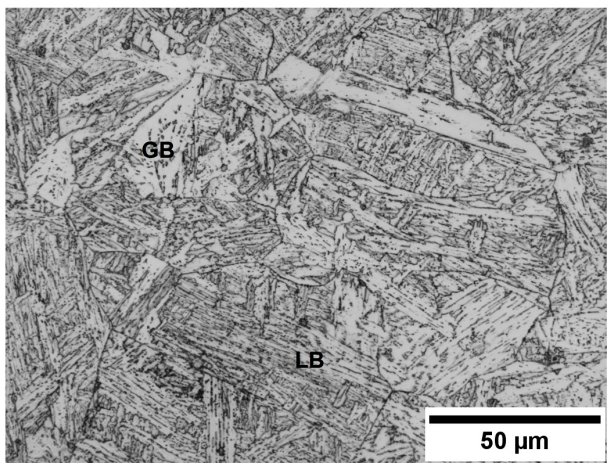

(b) $3 \mathrm{~mm}, \mathrm{LB}+\mathrm{GB}+$ micro-phases along the grain boundary

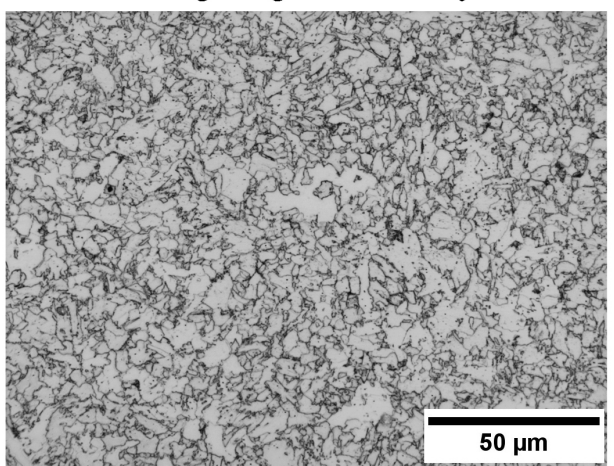

(d) $5 \mathrm{~mm}, \mathrm{PF}$

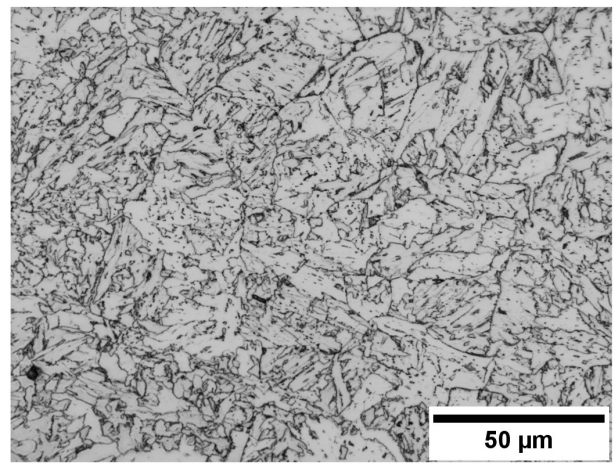

(f) $8 \mathrm{~mm}, \mathrm{~GB}+$ micro-phases along the grain boundary

Figure 13. Evolution of the microstructure along the thickness at $0.25 \mathrm{~mm}$ from the fusion line after etching with nital $2 \%$ (OM). Where: LB - Lath bainite; GB - Granular bainite; PF - Polygonal ferrite. 


\subsection{Concerns about safe welding procedures}

Sharma et al. ${ }^{1}$ reviewed the possible causes of failures in pipelines and observed that the critical issues and challenges in welding of pipes are corrosion, hydrogen embrittlement, residual stresses and the deteriorated heat affected zone which adversely affects the performance of a welded structure. However, the authors did not mention the influence of the microstructure in their work. The only comment made was that an improvement in the microstructure of the HAZ, would also improve the properties of the welded joint, but did not go into details. Another issue is the fact that in a real welded joint, the HAZ regions are narrow in relation to the weldment, which makes it difficult to pinpoint the local where the material or component is most likely to fail during its service period. So, usually to assess and elucidate the effect of welding thermal cycles on the mechanical properties of HAZ, simulations of the welding temperature cycles are used as the appropriate approach ${ }^{75}$. However, as shown in this work, it does not mirror the behavior of the welded joint, because multipass welding presents a completely different behavior.

Briefly speaking, the multipass welding of thick sections of high strength steels used for the manufacturing and joining of transmission pipelines presents a number of metallurgical challenges ${ }^{11}$. Basically, two main problems are related to the softening phenomenon and the presence of LBZ at the ICCGHAZ next to the fusion line. The former is not a problem for impact toughness because the presence of polygonal ferrite promotes high Charpy- $\mathrm{V}$ results, although it can impair the mechanical strength when the difference in hardness is $20 \%$ greater than the base metal ${ }^{14,65,68,74}$. However, the latter can be a significant problem because the toughness is indubitably affected by the presence of a 'necklace' of micro-phases around the prior austenite grain boundaries ${ }^{65,73,76}$. Recently, MA constituents have been under scrutiny because their significance on mechanical properties is ambiguous, particularly in terms of tensile and toughness properties. The role of MA on mechanical properties has become a more active research subject due to a lack of knowledge combined with contradictory evidence.

The results showed in this work evidence a critical issue of the knowledge involved when MA constituent is the subject and the industrial needs. The majority of works have develop important and consistent knowledge about the mechanisms of formation of the micro-phases incorporating the relevance of the influence of their size, distribution and volume fraction on the properties, which is very useful for a better understanding of all metallurgical aspects. However, the precise influence of the LBZ on the structural integrity of large equipment manufactured by welding in still unclear.

In this respect, it is important to emphasize that the most meticulous academic investigations about this subject are conducted by using thermal simulations, where a very small part of the welded joint is evaluated and its properties are predicted. At this point, the main question is: what portion of the HAZ is effectively composed of this microstructure?

On the other hand, on the industrial scale, this knowledge cannot be ignored when qualifying welding procedures, if the presence of LBZ is a real possibility.
In this work, an effort to contemplate academic and technological aspects was made. The objective was to provide safer welded structures. This work showed that industrial welded joints even those that achieved the requirements of several different and stringent Standards are susceptible to serious damage, even when only $40 \%$ of the thickness contains a poor microstructure. Thus, the current Standards ${ }^{3,42-52}$ must be able to assess these critical areas and guarantee the effectiveness of their approved procedures. As seen before, this is not the case here. Additionally, the continuous film along the grain boundary consists of carbides and MA constituents. The main contribution of this work is that it shows the critical contribution of necklace structures to low toughness, since its formation is unavoidable in multipass weldments. The point is to know how to control the size and fraction of these necklace-like micro-phases once they are formed ${ }^{9}$.

The macrograph of the welded joint in Figure 14 indicating the position of the Charpy-V notch clearly shows that the requirements of the current Standards ${ }^{3,42-52}$ are unable to evaluate the critical region of the HAZ when approving welding procedures. According to the Standards ${ }^{46,49-51}$, the notch is positioned at the fusion line, as well as 2.0 and $5.0 \mathrm{~mm}$ from the fusion line and, considering the $\mathrm{V}$-grooves geometry, the fusion line means that $50 \%$ of the notch is in weld metal (Figure 14). Even using a square groove as simulated in the present work (Figure 3), the positioning of the notch entirely in the HAZ is a complex task. This is because the extension of the HAZ is small $(3.2 \mathrm{~mm}$ in this work) and it is not exactly perpendicular to the top surface as ideally designed (Figure 1), due to the execution of multiple welding passes using different welding electrical parameters for each pass. Additionally, the difference in heat flow at the center of the thickness and near the top surface and root is another issue. Furthermore, the difficulty to guarantee precision when working with test specimens machined but not polished is well recognized. In spite of all these details, it is clear that the square groove is much more appropriate than the V-groove to evaluate the properties of the HAZ, in order to assess this critical region.

Recognizing the complexity of using this configuration in regular welding operations, we would like to propose the adoption of the Semi V-type groove for the qualification of welding procedures and the use of the V-groove for production operations, based on the argument that more complex procedures are able to qualify simpler ones. This already happens for ASME IX ${ }^{77}$, when considering the chemical composition, welding position, etc. In this case, the Charpy- $\mathrm{V}$ notch can be positioned as close as possible to the fusion line as suggested by the API-6 $\mathrm{A}^{45}$, in complement to the positions required ${ }^{4-52}$, to increase the chance to contemplate the critical region of the HAZ, as reported in the literature $7,14,16,18-21$ and confirmed by this work.

Finally, it is important to remember the need for additional Vickers hardness tests $\left(\mathrm{HV}_{10}\right)$ required by some Standards $^{51}$. In this respect, Figure 15 shows significant differences provided by both methods, due to the size of indentations and spacing between them. Thus, showing that microhardness tests are more appropriate to weldments where LBZ can exist. 


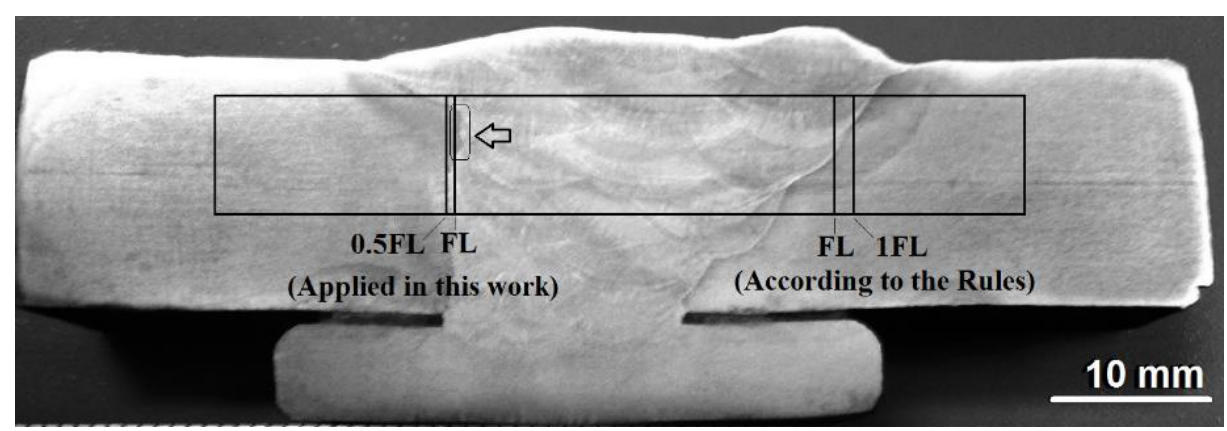

Figure 14. Positioning of notch along the fusion line and close to fusion line used in this work and required by the Standards for V-type grooves.

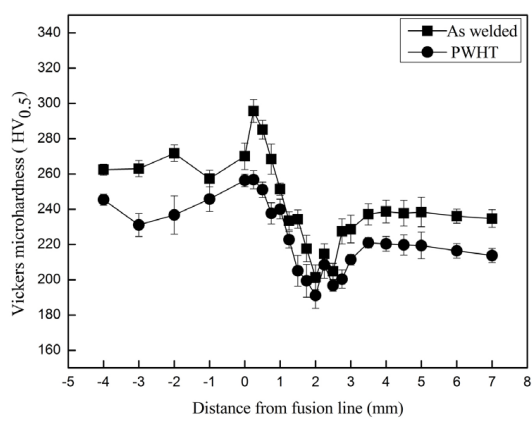

(a)

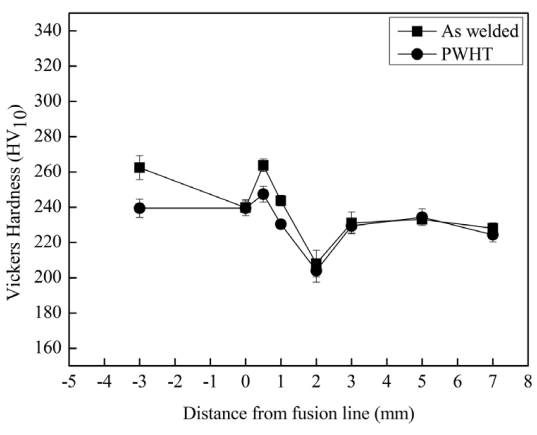

(b)

Figure 15. Comparative analysis between (a) microhardness $\left(\mathrm{HV}_{0.5}\right)$ and (b) hardness $\left(\mathrm{HV}_{10}\right)$.

Summarizing, the following procedures are recommended as complementary tests for the approval of safe welding procedures:

(a) Adoption of semi- $\mathrm{V}$ groove type for welding procedure qualifications. In the case no deleterious microstructure is detected, the use of V-groove type is acceptable for production joints;

(b) Implementation of additional Charpy- $\mathrm{V}$ tests with notch positioned as close as possible to the fusion line;

(c) Execution of microhardness tests to evidence the hardness values of the critical regions more precisely.

\section{Conclusions}

Based on the results and discussion of the present work, the main conclusions are:

a) API 5L X80 steel welded joint obtained by the SMAW process can achieve all requirements for approval of welding procedures according to the current Standards applied for different applications;

b) API 5L X80 welded joint showed very low impact toughness at $0.5 \mathrm{~mm}$ from the fusion line due to the presence of micro-phases decorating the prior austenite grain boundaries;

c) The continuous film responsible for the embrittlement observed at the HAZ are composed of MA constituents and carbides;

d) Despite the decomposition of MA constituents, the execution of PWHT is not effective to eliminate the embrittlement; e) The adoption of a semi V-groove to allow the positioning of Charpy- $\mathrm{V}$ at the critical region of the HAZ is proposed as an important change in the current Standards as necessary to improve their effectiveness for safer welding procedures.

\section{Acknowledgements}

The authors would like to thank the following Institutions for their support given during the execution of the present work: CEFET-RJ, PUC-RIO, CTEx, UFRJ, CNPq and FINEP.

\section{References}

1. Sharma SK, Maheshwari S. A review on welding of high strength oil and gas pipeline steels. J Nat Gas Sci Eng. 2017;38:203-17.

2. Godefroid LB, Sena BM, Trindade VB Fo. Evaluation of microstructure and mechanical properties of seamless steel pipes API 5L type obtained by different processes of heat treatments. Mater Res. 2017;20(2):514-22.

3. American Petroleum Institute. Specification for Line Pipe. 45. ed. Washington: API 5L; 2015.

4. Silva CC, Assis JT, Philippov S, Farias JP. Residual stress, microstructure and hardness of thin-walled low-carbon steel pipes welded manually. Mater Res. 2016;19(6):1215-25.

5. Cardoso RA, Faria GL. Characterization of austenite decomposition in steels with different chemical concepts and high potential to manufacture seamed pipes for oil and gas industry. Mater Res. 2019;22(5):e20190378. http://dx.doi.org/10.1590/19805373-MR-2019-0378.

6. Zhu Z, Kuzmikova L, Li H, Barbaro FJ. The effect of chemical composition on microstructure and properties of intercritically 
reheated coarse grained heat affected zone in X70 steels. Metall Mater Trans, B, Process Metall Mater Proc Sci. 2013;45(1):22935.

7. Guillal A, Abdelbaki N, Gaceb M, Bettayeb M. Effects of martensite-austenite constituents on mechanical properties of heat affected zone in high strength pipeline steels-review. Chem Eng Trans. 2018;70:583-8.

8. Kim S, Kang D, Kim T-W, Lee J, Lee C. Fatigue crack growth behavior of the simulated HAZ of $800 \mathrm{MPa}$ grade high performance steel. Mater Sci Eng A. 2011;528:2331-8.

9. Wang X, Wang Z, Xie ZY, Ma X, Subramanian S, Shang C, et al. Combined effect of $\mathrm{M} / \mathrm{A}$ constituent and grain boundary on the impact toughness of CGHAZ and ICCGHAZ of E550 grade offshore engineering steel. Math Biosci Eng. 2019;16(6):7494509.

10. You Y, Shang C, Chen L, Subramanian S. Investigation on the crystallography of the transformation products of reverted austenite in intercritically reheated coarse grained heat affected zone. Mater Des. 2013;43:485-91.

11. Mandal M, Poole W, Garcin T, Militizer M, Collins L. Mechanical behavior of intercritically reheated coarse-grained heat affected zone in high strength line pipe steels. In 12th International Pipeline Conference; 2018 Sep 24-28; Calgary, Alberta, Canada. Proceedings. USA: ASME. Paper IPC2018-78317.

12. Wang X, Wang X, Shang C, Misra R. Characterization of the multi-pass weld metal and the impact of retained austenite obtained through intercritical heat treatment on low temperature toughness. Mater Sci Eng A. 2016;649:282-92.

13. Wang X, Nan Y, Xie Z, Tsai, Y. T., Yang, J. R., Shang, C. J. Influence of welding pass on microstructure and toughness in the reheated zone of multi-pass weld metal of $550 \mathrm{MPa}$ offshore engineering steel. Mater Sci Eng A. 2017;702:196-205.

14. Batista GZ, Carvalho LP, Silva MS, Souza MP. Girth welding of API 5L X70 and X80 sour service pipes. Weld J. 2016;95(10):36370.

15. Ding Q, Wang T, Shi Z, Wang Q, Wang Q, Zhang F. Effect of welding heat input on the microstructure and toughness in simulated CGHAZ of $800 \mathrm{MPa}$ - grade steel for hydropower penstocks. Metals (Basel). 2017;7(4):115. http://dx.doi. org $/ 10.3390 /$ met7040115

16. Albuquerque SF, Silva RS, Maciel TM, Almeida DM, Bracarense AQ. Study on the behavior of API 5L X80 steel when subjected to automated welding process. Soldag Insp. 2012;17(2):137-46.

17. Mohseni P, Solberg JK, Karlsen M, Akselsen OM, Ostby E. Cleavage fracture initiation at M-A constituents in intercritically coarse grained heat affected zone of a HSLA steel. Metall Mater Trans, A Phys Metall Mater Sci. 2014;45:384-94.

18. Luo X, Chen X, Wang T, Pan S, Wang Z. Effect of morphologies of martensite-austenite constituents on impact toughness in intercritically reheated coarse grained heat affected zone of HSLA steel. Mater Sci Eng A. 2018;710:192-9.

19. Lee SG, Sohn SS, Kim B, Kim WG, Um KK, Lee S. Effects of martensite-austenite constituent on crack initiation and propagation in inter-critical heat-affected zone of high-strength low-alloy (HSLA) steel. Mater Sci Eng A. 2018;715:332-9.

20. Li X, Shang C, Ma X, Subramanian SV, Misra RDK, Sun J. Structure and crystallography of martensite-austenite constituent in the intercritically reheated coarse grained heat affected zone of a high strength pipeline steel. Mater Charact. 2018;138:10712.

21. Li Z, Zhao X, Shan D. Impact toughness of subzones in the intercritical heat-affected zone of low-carbon bainitic steel. Materials (Basel). 2018;11(6):959. http://dx.doi.org/10.3390/ ma11060959.

22. Li X, Ma X, Subramanian SV, Shang C, Misra RDK. Influence of prior austenite grain size on martensite-austenite constituent and toughness in the heat affected zone of $700 \mathrm{MPa}$ high strength linepipe steel. Mater Sci Eng A. 2014;616:141-7.
23. Haugen VG, Rogne BRS, Akselsen OM, Thaulow C, Østby E. Local mechanical properties of intercritically reheated coarse grained heat affected zone in low alloy steel. Mater Des. 2014;59:135-40.

24. Lambert A, Drillet J, Gourgues AF, Sturel T, Pineau A. Microstructure of martensite-austenite constituents in heat affected zones of high strength low alloy steel welds in relation to toughness properties. Sci Technol Weld Join. 2000;5:168-73.

25. Di XJ, Cai L, Xing XX, Chen CX, Xue ZK. Microstructure and mechanical properties of intercritical heat-affected zone of X80 pipeline steel in simulated in-service welding. Acta Metall Engl Lett. 2015;28:883-91.

26. Liu C, Zhao ZB, Northwood DO. Mechanical properties of heat affected zone in bainitic high strength low alloy steel. Mater Sci Technol. 2002;18:1325-8.

27. Li Y, Baker TN. Effect of morphology of martensite-austenite phase on fracture of weld heat affected zone in vanadium and niobium microalloyed steels. Mater Sci Technol. 2010;26:102940.

28. Kong X, Lan L, Hu Z, Li B, Sui T. Optimization of mechanical properties of high strength bainitic steel using thermo-mechanical control and accelerated cooling process. J Mater Process Technol. 2015;217:202-10.

29. Kaplan D, Lambert-Perlade A. Influence of martensite-austenite constituents on heat affected zone toughness of C-Mn steel welds. Rev Metal. 2001;98:889-98.

30. Davis CL, King JE. Cleavage initiation in the intercritically reheated coarse-grained heat-affected zone: Part I. Fractographic evidence. Metall Mater Trans, A Phys Metall Mater Sci. 1994;25:563-73.

31. Li B, Li C, Jin X, Zhang J. Effect of M-A constituents formed in thermo-mechanical controlled process on toughness of 20CrNi2MoV steel. J Iron Steel Res Int. 2019;26:1340-49. http://dx.doi.org/10.1007/s42243-019-00244-8.

32. Caballero FG, Roelofs H, Hasler S, Capdevila C, Chao J, Cornide $\mathrm{J}$, et al. Influence of bainite morphology on impact toughness of continuously cooled cementite free bainitic steels. Mater Sci Technol. 2012;28(1):95-102.

33. Chen J, Tang S, Liu ZY, Wang GD. Microstructural characteristics with various cooling paths and the mechanism of embrittlement and toughening in low-carbon high performance bridge steel. Mater Sci Eng A. 2013;559:241-9.

34. Sun XJ, Yuan SF, Xie ZJ, Dong LL, Shang CJ, Misra RDK. Microstructure-property relationship in a high strength-high toughness combination ultra-heavy gauge offshore plate steel: the significance of multiphase microstructure. Mater Sci Eng A. 2017;689:212-9.

35. Wang XL, Wang ZQ, Ma XP, Subramanian SV, Xie ZJ, Shang $\mathrm{CJ}$, et al. Analysis of impact toughness scatter in simulated coarse-grained HAZ of E550 grade offshore engineering steel from the aspect of crystallographic structure. Mater Charact. 2018;140:312-9.

36. Zhong Y, Xiao FR, Zhang JW, Shan Y, Wang W, Yang K. In situ TEM study of the effect of M/A films at grain boundaries on crack propagation in an ultra-fine acicular ferrite pipeline steel. Acta Mater. 2006;54:435-43.

37. Li XD, Ma XP, Subramanian SV, Shang C, Misra RDK. Influence of prior austenite grain size on martensite-austenite constituent and toughness in the heat affected zone of $700 \mathrm{MPa}$ high strength linepipe steel. Mater Sci Eng A. 2014;616:141-7.

38. Li J, Zhang C, Liu Y. Influence of carbides on the high temperature tempered martensite embrittlement of martensitic heat-resistant steels. Mater Sci Eng A. 2016;670:256-63. http:// dx.doi.org/10.1016/j.msea.2016.06.025.

39. Laitila J, Larkiola J. Effect of enhanced cooling on mechanical properties of a multipass welded martensitic steel. Weld World. 2019;63:637-46. 
40. Wen C, Deng X, Tian Y, Wang Z, Misra RDK. Microstructural evolution and toughness of the various HAZs in 1300-MPagrade ultrahigh-strength structural steel. J Mater Eng Perform. 2019;28:1301-11.

41. Qiao G, Han X, Chen X, Wang X, Liao B, Xiao F. Transformation of $\mathrm{M} / \mathrm{A}$ constituents during tempering and its effects on impact toughness of weld metals for X80 hot bends. Advances in Materials Science and Engineeringhttps. 2019:6429045. http:// dx.doi.org/10.1155/2019/6429045.

42. Wang XL, Wang XM, Shang CJ, Misra RDK. Characterization of the multi-pass weld metal and the impact of retained austenite obtained through intercritical heat treatment on low temperature toughness. Mater Sci Eng A. 2016;649:282-92.

43. Kim JH, Yoon EP. Notch position in the HAZ specimen of reactor pressure vessel Steel. J Nucl Mater. 1998;257:303-8.

44. Det Norske Veritas. Submarine Pipeline Systems. DNV-OS-F101. Oslo: Det Norske Veritas; 2013.

45. American Petroleum Institute. Specification for wellhead and christmas tree equipment. API 6A. 4th ed. Washington: API; 2008.

46. American Bureau of Shipping. Materials and welding. Houston, Texas, EUA: ABS Plaza; 2018. 459 p

47. American Petroleum Institute. Welding of pipelines and related facilities. API 1104. Washington: API; 2016. 121 p. ADDENDUM.

48. American Welding Society. AWS D1.1/D1.1M:2015: Structural Welding Code - Steel. 23rd ed. United States of America: American Welding Society; 2015. 604 p.

49. Bureau Veritas. BV NR 216: Rules on Materials and Welding for the Classification of Marine Units. Paris: BV; 2018. 260 p.

50. Bureau Veritas. BV NR 426: Construction Survey of Steel Structures of Offshore Units and Installations. Paris: BV; 2006. $34 \mathrm{p}$.

51. Det Norske Veritas. Offshore Standards - Fabrication and testing of offshore structures. DNVGL-OS-C401. Oslo: Det Norske Veritas; 2018. 129 p.

52. CONTEC: Comissão de Normalização Técnica. Petrobras Petróleo Brasileiro. N-1852: Estruturas Oceânicas - Fabricação e Montagem de Unidades Fixas. Brasil: CONTEC; 2017. 58 p. Revalidada em 07/2017.

53. Bai F, Ding H, Tong L, Pan L, Wang L. Microstructural changes and impact toughness of fill pass in X80 steel weld metal. Metals (Basel). 2019;9:898. http://dx.doi.org/10.3390/met9080898.

54. Karlsson L, Svensson LE, Hurtig K. Influence of dilution on properties of high strength steel weld metals. Biulettin Institute Spawalnictwa. 2014;5:62-70.

55. Jorge JCF, Souza LFG, Couto JLS, Bott IS. Influence of chemical composition on the mechanical properties of high strength steel weld metals for application in mooring components. International Journal of Engineering and Technical Research. 2016;4(2):71-6.

56. Kitagawa Y, Kawasaki H. Recent development of high-strength and tough welding consumables for offshore structures. Kobelco Technol Rev. 2013;32(12):1-8.

57. Lins AS Jr, Costa HRM, Souza LFG, Jorge JCF. Propriedades mecânicas e microestruturais de juntas soldadas do aço HY80 pelos processos eletrodo revestido e GMAW. Soldag Insp. 2014;19(3):200-11.

58. Farneze HN, Jorge JCF, Souza LFG, Bott IS. Comparative study of high-strength steel weld metals obtained by the SMAW and FCAW processes for offshore applications and mooring chains. Welding Internatinal. 2010;24:903-10.

59. Surian ES, Rissone NMR, Svoboda HG, Rep R, de Vedia LA. SMAW, FCAW and SAW high-strength ferritic deposits: the challenge is tensile properties. Weld J. 2010;89(3):54-64.

60. Svensson LE. Consumables for welding high strength steels. Svetsaren. 1999;1:30-3.

61. Wang HH, Li GQ, Wan XL, Nune KC, Li Y, Wu KM. Microstructural characteristics and impact toughness in
YS690MPa steel weld metal for offshore structures. Sci Technol Weld Join. 2017;22(2):133-42.

62. Wang ZQ, Wang XL, Nana YR, Shang CJ, Wang XM, Liu $\mathrm{K}$, et al. Effect of Ni content on the microstructure and mechanical properties of weld metal with both-side submerged arc welding technique. Mater Charact. 2018;38:67-77.

63. Zhang L, Pittner A, Michael T, Rhode M, Kannengiesser T. Effect of cooling rate on microstructure and properties of microalloyed HSLA steel weld metals. Sci Technol Weld Join. 2015;20(5):371-7.

64. Zhang T, Li Z, Ma S, Kou S, Jing H. High strength steel (600$900 \mathrm{MPa}$ ) deposited metals: microstructure and mechanical properties. Sci Technol Weld Join. 2016;21(3):186-93.

65. Arora KS, Pandu SR, Shajan N, Pathak P, Shome M. Microstructure and impact toughness of reheated coarse grain heat affected zones of API X65 and API X80 linepipe steels. Int J Press Vessels Piping. 2018;163:36-44.

66. Li X, Fan Y, Ma X, Subramanian SV, Shang C. Influence of martensite-austenite constituents formed at different intercritical temperatures on toughness. Mater Des. 2014;67:457-63.

67. Li X, Shang C, Ma X, Gault B, Subramanian SV, Sun J, et al. Elemental distribution in the martensite-austenite constituent in intercritically reheated coarse-grained heat-affected zone of a high-strength pipeline steel. Scr Mater. 2017;139:67-70.

68. Kim C, Lee J, Yoo J. A study on the metallurgical and mechanical characteristics of the weld joint of X80 steel. In: 15th International Offshore and Polar Engineering Conference; 2005 June 19-24; Seoul, Korea. Proceedings. USA: ISOPE; 2005. p. 158-162.

69. He X, Tong K, Liang M, Zhu L, Lin W. Properties of X80 pipeline girth welds for different welding procedures. Adv Mat Res. 2014;936:1747-53.

70. Efimenko LA, Kapustin OE, Ramus AA, Ramus RO. Control of softening processes in the heat-affected zone during welding of high-strength steels. Metal Sci Heat Treat. 2016;58(7-8):435-41.

71. Yin L, Wang J, Chen X, Liu C, Siddiquee AN, Wang G, et al. Microstructures and their distribution within HAZ of X80 pipeline steel welded using hybrid laser-MIG welding. Weld World. 2018;62:721-7.

72. Lilang L, Chaofan Z, Yu L, Shumao S, Hui Y. Evaluation of softening zone in $\mathrm{X} 80$ pipeline steels under tension-bending load. Mater Sci Eng. 2018;398:012035. http://dx.doi.org/10.1088/1757899X/398/1/012035.

73. Gu Y, Xiao F, Zhou Y, Li J, Xu C, Zhou X. Behaviors of embrittlement and softening in heat affected zone of high strength X90 pipeline steels. Soldag Insp. 2019;24:1-10.

74. Pisarski HG, Dolby RE. The significance of softened HAZs in high strength structural steels. Weld World. 2003;47(5-6):32-40.

75. Celin R, Burja J, Kosec G. A comparison of as-welded and simulated heat affected zone (HAZ) microstructure. Mater Technol. 2016;50:455-60.

76. Andia JLM, Souza LFG, Bott IS. Microstructural and mechanical properties of the intercritically reheated coarse grained heat affected zone (ICCGHAZ) of an API 5L X80 pipeline steel. Mater Sci Forum. 2014;783-786:657-62.

77. American Society of Mechanical Engineers. ASME boiler and pressure vessel code - qualification standard for welding, brazing, and fusing procedures; welders; brazers; and welding, brazing, and fusing operators, Section IX. USA: ASME; 2015. 